\begin{tabular}{|c|c|c|}
\hline 150 & $\begin{array}{c}\text { Bulletin of Pharmaceutical Sciences } \\
\text { Assiut University }\end{array}$ & \\
\hline 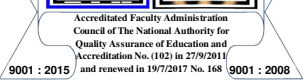 & $\begin{array}{c}\text { Website: http://bpsa.journals.ekb.eg/ } \\
\text { e-mail: bullpharm@aun.edu.eg }\end{array}$ & $\begin{array}{l}\text { BULL. PHARM. SCI. } \\
\text { Assiut Univ. }\end{array}$ \\
\hline
\end{tabular}

\title{
THE PHYTOCHEMICAL SCREENING AND ANTIOXIDANT POTENTIAL OF CINNAMOMUM JAVANICUM BLUME LEAVES FROM CENTRAL KALIMANTAN
}

\author{
Syahrida Dian Ardhany $^{1 *}$, Susi Novaryatiin ${ }^{1}$ and Nanang Hanafi ${ }^{2}$ \\ ${ }^{1}$ Department of Pharmacy, Faculty of Health Sciences, Muhammadiyah University of \\ Palangkaraya, Palangka Raya, Central Kalimantan, Indonesia \\ ${ }^{2}$ Department of Forestry, Faculty of Agriculture and Forestry, Muhammadiyah University of \\ Palangkaraya, Palangka Raya, Central Kalimantan, Indonesia
}

\begin{abstract}
Background: Sintok lancang (Cinnamomum javanicum Blume.) is one of the typical plant of Central Kalimantan, which has not been widely studied. Local people use leaves of $C$. javanicum to treat various diseases, like diabetes and skin diseases. Based on this, it is necessary to do preliminary study to know phytochemical content and antioxidant potential that may be contained in this plant. Methods: C. javanicum leaves were extracted using percolator with $96 \%$ ethanol. The extract was tested for qualitative phytochemical with standard procedures, while the antioxidant test was carried out using 1,1-diphenyl-2-picrylhydrazyl $(D P P H)$ method with quercetin as standard and ferric reducing antioxidant power (FRAP) with trolox as standard. Results: The result showed ethanolic extract of $C$. javanicum leaves qualitative phytochemical contained alkaloid, flavonoid, tannin and steroid. Antioxidant activity test showed leaves of $C$. javanicum with DPPH method $I C_{50}=26.99 \pm 0.27$ ppm and antioxidant activity with FRAP method $779.73 \pm 19.66$ umoltrolox/g. Conclusion: It can be concluded that C. javanicum leaves have potential high antioxidant activity was tested with DPPH and FRAP method. Furthermore need further research, especially to determine specific compound of $C$. javanicum leaves.
\end{abstract}

\section{INTRODUCTION}

Central Kalimantan is one of the tropical forest areas in Indonesia which has biodiversity especially natural medicine but has not been fully utilized. Traditional uses such as traditional medicine have been done, but further exploration and development have not been done much. Sintok lancang leaves (Cinnamomum javanicum Blume.) are one of the typical Central Kalimantan plants that have not been studied much, it's found in the Mungku Baru forest (Kawasan Hutan Dengan Tujuan Khusus) or educational forest managed by the Muhammadiyah University of Palangkaraya collaboration with the Borneo Nature Foundation (BNF). Local people use sintok lancang leaves for various diseases such as to treat abdomen pain, wounds, and diabetes.

There have not been many studies on Cinnamomum javanicum, especially those that grow in Indonesia, but one of the researches at the University of Jember states that different species, Cinnamomum Sintoc leaves has the potential as an antioxidant because it contains secondary metabolites such as flavonoids, alkaloids, steroids, terpenoids, and tannins which could prevent the free radical $^{1-3}$. Antioxidant use is associated with reduced production of ROS (Reactive oxygen species) and free radicals $\mathrm{s}^{4-6}$. According to previous pieces of evidence, ROS have been implicated in the pathogenesis of various diseases such as cancer, aging, and other diseases. In addition, research related to natural antioxidants are

Received in 4/2/2021 \& Accepted in 5/3/2021 
considered to contribute to the therapeutic approach in the treatment of COVID-19, although their mechanism against COVID-19 is still unknown and speculative ${ }^{7}$. Several studies provide evidence that a reduction in ROS accumulation slows the apoptosis signaling activated by a coronavirus ${ }^{8}$.

In this study, the determination was carried out the total flavonoids, alkaloids and tannins compounds of Cinnamomum javanicum leaves. Antioxidant activity test was conducted by using DPPH and FRAP assay. The present data would help to explore the potential of Indonesia's natural plants, especially plants that have not been studied much so it can be further developed for the cosmetic, food and pharmaceutical industries.

\section{METHODS}

\section{Plant collection and identification}

Fresh leaves of sintok lancang (Fig. 1) were collected in the Mungku Baru forest (Kawasan Hutan Dengan Tujuan Khusus) or educational forest managed by the Muhammadiyah University of Palangkaraya collaboration with the Borneo Nature Foundation (BNF), Palangka Raya, Central Kalimantan and authenticated by Dr. R. Hendrian, M.Sc from Indonesia Institute of Sciences, Research Center for Plant Conservation and Botanic Gardens, Bogor, Indonesia.

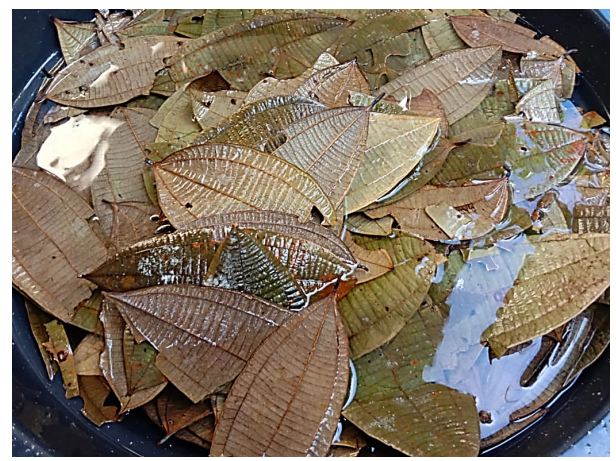

Fig. 1: Sintok lancang (Cinnamomum javanicum Blume.).

\section{Preparation of Plant Extract}

The whole fresh leaves were washed, cleaned and dried in oven at $45^{\circ} \mathrm{C}^{9 \& 10}$. Generally, the oven drying method is used for herb drying in the temperature range of 40 - $60^{\circ} \mathrm{C}^{11}$. The dried leaves were grindered and powdered. Extracted with ethanol $96 \%$ by percolation. Percolation is better than maceration because it is a continuous process in which the saturated solvent is constantly being replaced by fresh solvent ${ }^{12}$. The extract were concentrated in a rotary evaporator. The percentage yields $(\mathrm{w} / \mathrm{w})$ of the extracts were calculated using the formula ${ }^{13}$ :

(Weight of extract $\div$ Weight of starting plant material) $\mathrm{x} 100 \%$

\section{Phytochemical qualitative screening}

The ethanolic extract of sintok lancang leaves ( $C$. javanicum Blume) was screened for potential presence of alkaloid, flavonoids, tannins, saponins, and steroids by using the following standard methods ${ }^{14-17}$.

\section{Determination of the total alkaloid content}

Ten $\mathrm{mg}$ extract of $C$. javanicum was weighed then dissolved in $10 \mathrm{ml}$ ethanol. One $\mathrm{ml}$ extract was measured the absorbance with a spectrophotometer at $272 \mathrm{~nm}$. The standard used for the calibration curve was caffeine ${ }^{18}$. The total alkaloid content was expressed as micrograms of alkaloids per milligrams of the extract.

\section{Determination of the total flavonoid content}

Five $\mathrm{mg}$ extract of $C$. javanicum was weighed then dissolved in $10 \mathrm{ml}$ ethanol. One $\mathrm{ml}$ extract was placed in the volumetric flask, one $\mathrm{ml} \mathrm{AlCl}_{3}(2 \% \mathrm{~b} / \mathrm{v})$ and $8 \mathrm{ml}$ acetic acid (5\% $\mathrm{v} / \mathrm{v}$ ) were added. After mixing, the solution was incubated for 20 minutes ${ }^{19 \& 20}$. The solution was measured the absorbance with a spectrophotometer at $412 \mathrm{~nm}$. The standard used for the calibration curve was quercetin ${ }^{21}$. The total flavonoid content was expressed as micrograms of flavonoids per milligrams of the extract.

\section{Determination of the total tannin content}

A total of $30 \mathrm{mg}$ of sample was weighed and put into a $10 \mathrm{ml}$ volumetric flask. The solution of $0.5 \mathrm{ml}$ was added with $3.0 \mathrm{ml}$ of vanillin $4 \%$ and $1.5 \mathrm{ml}$ of concentrated $\mathrm{HCl}$. The mixture was incubated for 10 minutes $^{21-24}$. The absorbance was measured with UV Vis spectrophotometer at $498 \mathrm{~nm}$. The standard used for the calibration curve was catechin ${ }^{25}$. The total tannin content was expressed as micrograms of tannins per milligrams of the extract. 
Antioxidant activity test with DPPH method

DPPH solution with $0.4 \mathrm{mM}$ concentration was prepared, the absorbance was measured at $512 \mathrm{~nm}$. The absorbance result of the DPPH solution was the absorbance control. The extract of sintok lancang leaves (sample) were first dissolved in methanol with five different concentrations of 10,20,30,40, and $50 \mathrm{ppm}$. One $\mathrm{ml}$ of $0.4 \mathrm{mM}$ DPPH solution was placed into a $5 \mathrm{ml}$ volumetric flask, then added with 4 $\mathrm{ml}$ of sample solution each of various concentrations. The mixture was stored for incubation for $30 \mathrm{~min}$ at room temperature, the absorbance was measured at maximum wavelength $(512 \mathrm{~nm})^{26 \& 27}$. The percent inhibition or DPPH scavenging effect was calculated using the following formula:

DPPH scavenging effect $\%=\frac{(\mathrm{A}-\mathrm{B})}{\mathrm{A}} \times 100 \%$

Where, A was the absorbance of DPPH solution and B was the absorbance of sample solution $^{28 \& 29}$.

\section{Antioxidant activity test with FRAP method}

Sample $(0.2 \mathrm{~g})$ dissolved with ethanol with $10 \mathrm{ml}$ volumetric flask. Two $\mathrm{ml}$ of sample solution was added to $3 \mathrm{ml}$ of FRAP reagent in a test tube, then incubation for 16 minutes. The absorbance was measured with UV Vis spectrophotometer at $595 \mathrm{~nm}$. Antioxidant activity was expressed as $\mu$ mol trolox $/ \mathrm{g}^{28 \& 30}$.

\section{RESULTS AND DISCUSSION}

\section{Results \\ Yield of the extract}

Four hundred grams of $C$. javanicum fresh leaves were extracted into $51.1 \mathrm{~g}$ of extract. Based on the rendement calculation, the extraction of C. javanicum yields of $12.8 \%$. Value yield is related to the number of secondary metabolites that successfully attracted when the extraction process ${ }^{13}$.

\section{Phytochemical qualitative screening}

Phytochemical screening of $C$. javanicum leaves by using the following standard methods ${ }^{14-17}$. The results of the phytochemical qualitative test of sintok lancang leaves showed the presence of alkaloids using Mayer's reagents $^{31}$, flavonoids using the Shinoda test ${ }^{32}$, tannins and steroids (Table 1).
Table 1: The qualitative phytochemical of ethanolic extract $C$. javanicum leaves.

\begin{tabular}{||c|c|}
\hline Phytochemical compound & Result \\
\hline Alkaloids & + \\
\hline Flavonoids & + \\
\hline Tannins & + \\
\hline Steroids & + \\
\hline Saponins & - \\
\hline
\end{tabular}

Antioxidant activity, total alkaloid, flavonoid and tannin content

Ethanolic extract of $C$. javanicum leaves was conducted using percolation method. Antioxidant potential (DPPH \& FRAP), total alkaloid content, total flavonoid content and total tannin content was calculated with standard protocols.

The results of antioxidant activity showed that the $\mathrm{IC}_{50}$ value of $\mathrm{DPPH}$ was $26.99 \pm 0.27$ ppm quercetin equivalent while the FRAP method was $779.73 \pm 19.66 \mu \mathrm{mol}$ trolox/g. Total alkaloid, flavonoid, and tannin content respectively was $20.82 \pm 1.31 \mu \mathrm{g}$ caffeine equivalent/mg, $76.62 \pm 1.22 \mu \mathrm{g}$ quercetin equivalent $/ \mathrm{mg}$, and $23.02 \pm 0.24 \mu \mathrm{g}$ catechin equivalent/mg (Table 2 ).

Table 2: Antioxidant activity, total alkaloids, flavonoids and tannins content of ethanolic extract C. javanicum leaves.

\begin{tabular}{|l|c|c||}
\hline Assay Sample & $\begin{array}{c}\text { Ethanolic extract } \\
\text { of Cinnamomum } \\
\text { javanicum }\end{array}$ & Quercetin \\
\hline Antioxidant & $26.99 \pm 0.27$ & 6.98 \\
\hline $\begin{array}{l}\text {-DPPH }\left(\mathrm{IC}_{50}\right. \\
\text { ppm) }\end{array}$ & $779.73 \pm 19.66$ & - \\
\hline $\begin{array}{l}\text {-FRAP }(\mu \mathrm{mol} \\
\text { trolox/g) }\end{array}$ & $20.82 \pm 1.31$ & - \\
\hline $\begin{array}{l}\text { Total Alkaloid } \\
(\mu \mathrm{g} \text { caffeine } \\
\text { equivalent/mg) }\end{array}$ & $76.62 \pm 1.22$ & - \\
\hline $\begin{array}{l}\text { Total Flavonoid } \\
(\mu \mathrm{g} \text { quercetin } \\
\text { equivalent/mg) }\end{array}$ & $23.02 \pm 0.24$ & - \\
\hline $\begin{array}{l}\text { Total Tannin } \\
\text { ( } \mu \text { g catechin } \\
\text { equivalent } / \mathrm{mg})\end{array}$ & \multicolumn{2}{|l}{} \\
\hline
\end{tabular}




\section{Discussion}

Based on the results extract of $C$. javanicum leaves contain qualitative phytochemicals like flavonoid. Based on some literature flavonoids can prevent injury due to free radicals in various ways, one of which is the direct scavenging of free radicals. Flavonoids are oxidized by radicals, resulting in a more stable, less-reactive radical ${ }^{33 \& 34}$, such as the following equation:

Flavonoid $(\mathrm{OH})+\mathrm{R}^{*} \rightarrow$ Flavonoid $\left(\mathrm{O}^{*}\right)+\mathrm{RH}$

Besides that $C$. javanicum leaves contain alkaloids and tannins which may also potential contribute to the effectiveness of antioxidant ${ }^{35 \& 36}$. Alkaloids have antioxidant properties through capturing free radicals, or binding to catalysts involved indifferent oxidation processes occurring within the human body for preventing a variety of degenerative diseases ${ }^{37}$. The free radical scavenging activity of tannins showed by the ability of antioxidant to donate electron to a free radical and produce a more stable and therefore less harmful radical structure. Tannins are able to bond cations of transition metals and act as protective agents against progression of some diseases, e.g. Alzheimer's or Parkinson's disease. Antioxidant activity of tannins can also be exhibited through inhibition of prooxidative enzymes ${ }^{38}$.

There hasn't been much study on $C$. javanicum leaves. However, some studies have stated that C.javanicum found in Sumatra can reduce fever, others claim that it has antioxidant potential but there are no studies of C.javanicum that grows in Kalimantan ${ }^{39 \& 40}$.

Yuan et al stated that C.javanicum both leaf and stem extract showed antimicrobial activity against Listeria monocytogenes ${ }^{41}$. The essential oil of C.javanicum also showed antibacterial activities against four strains of food pathogenic bacteria: Staphylococcus aureus (ATCC 29213), Listeria monocytogenes (ATCC 7644), Salmonella typhimurium (ATCC 25922) and Salmonella enteritidis

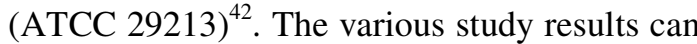
be the basis for further research.

According to some literature, antioxidant activity with DPPH method classified by $\mathrm{IC}_{50}$ into: very strong $(<50 \mathrm{ppm})$, strong $(50-100$ $\mathrm{ppm})$, moderate (101-150 ppm) and low (> 150 ppm $)^{28 \& 43}$, while antioxidant activity with FRAP method classified into very low FRAP $(<10 \mu \mathrm{mol} / \mathrm{g})$, low FRAP $(10-50 \mu \mathrm{mol} / \mathrm{g})$, good FRAP $(50-100 \mu \mathrm{mol} / \mathrm{g})$, high FRAP (100$400 \mu \mathrm{mol} / \mathrm{g}$ ), and very high FRAP (> 400 $\mu \mathrm{mol} / \mathrm{g})^{44}$. The ethanolic extract of $C$. javanicum leaves included in the very strong antioxidant activity $(26.99 \pm 0.27 \mathrm{ppm})$ and very high FRAP $(779.73 \pm 19.66 \mu$ mol trolox/g). When compared with $C$. javanicum leaves study conducted in Malaysia with DPPH method $(223.5 \mathrm{ppm})^{45}$, C. javanicum leaves in Indonesia, especially Central Kalimantan give better antioxidant activity.

DPPH is a stable free radical with an unpaired electron that is delocalized over the entire molecule. The DPPH assay is based on both electron transfer and hydrogen atom transfer reactions. The benefits of the DPPH assay is easy to do, rapid method and economic. Even though the DPPH assay is simple, its sensitivity may be affected by several factors, such as the type of solvent, reaction time, temperature and freshness of DPPH reagent ${ }^{46 \& 47}$, while the FRAP assay is a non-specific, redox-linked, colorimetric assay that is related to the molar concentration of the antioxidant present. The FRAP assay is a typical electron transfer based method that measures the reduction of ferric ion $\left(\mathrm{Fe}^{3+}\right)$ ligand complex to the ferrous $\left(\mathrm{Fe}^{2+}\right)$ complex by antioxidants in acidic media. One limitation of FRAP assay is the tendency to precipitate, forming a suspension and staining the measuring cuvette. Therefore, time to add $\mathrm{FeCl}_{3}$ is essential to prevent error interpretation. However, the FRAP or DPPH assay is simple, economic, rapid and not require specialized equipment ${ }^{47}$.

Antioxidants are widely used for protection of various diseases such as coronary heart, cancer. Besides that, it is also often applied at the industrial level such as cosmetic for anti-aging and acne ${ }^{48}$. The role of the food industry and mass media were explored to focus on health promotion of the older person in the present ${ }^{49}$.

Based on the results $C$. javanicum leaves has the potential to be cultivated to keep sustainability and developed into antioxidant material. 


\section{Conclusion}

It can be concluded ethanolic extract of $C$. javanicum leaves has the potential high antioxidant activity tested by DPPH and FRAP methods. Furthermore, it is necessary to further identify the specific compounds that have antioxidant activity in $C$. javanicum leaves.

\section{Acknowledgments}

This research was funded by a RisetMu grant batch 4 from Majelis Diktilitbang PP Muhammadiyah.

\section{REFERENCES}

1. A. Kumalasari, W. Handayani and T. S. Siswoyo, "Screening Fitokimia dan Studi Aktivitas Ekstrak Daun Sintok (Cinnamomum sintoc BI.) sebagai Antioksidan dan Antihiperlipidemia", Berkala Sainstek, VII (1), 24-27 (2019).

2. S. Jiamworanunkul, "Effective antioxidant production through submerged fermentation of edible mushrooms", Thai. J. Pharm. Sci., 43 (4), 213-218 (2019).

3. D. Stagos, "Antioxidant activity of polyphenolic plant extracts", Antioxidants, 9 (19) (2020).

4. L. S. Borquaye, M. K. Laryea, E. N. Gasu, M. A. Boateng MA, P. K. Baffour, A. Kyeremateng and G. Doh, "Antiinflammatory and antioxidant activities of extracts of Reissantia indica, Cissus cornifolia and Grosseria vignei", Cogent. Biology, 6, 1785755 (2020).

5. F. A. Fajrin, N. Imandasari, T. Barki, G. Sulistyaningrum, Afifah, N. Kristiningrum, E. Puspitasari and D. Holidah, "The activity of red ginger oil in antioxidant study in-vitro and antihyperalgesia effect in alloxan-induced painful diabetic neuropathy in mice", Thai. J. Pharm. Sci., 43 (2), 69-75 (2019).

6. N. Leakaya, V. H. Sato and S. Chewchinda, "Antioxidant activity, total phenolic, total flavonoid content and HPTLC analysis of morin in Maclura cochinchinensis Heartwood extract", Thai. J. Pharm. Sci., 42 (Supplement Issue), 27-31 (2018).

7. A. Al-Taie and A. O. Victoria, "Supplementary medicines and antioxidants in viral infections: A review of proposed effects for COVID-19", Biomed. Biotechnol. Res. J., 4 (1), 19-24 (2020).

8. L. R. L. Diniz, C. da. S. M. B. Filho, B. C. Fielding and D. P. de Sousa, "Natural Antioxidants: A review of studies oh human and animal coronavirus", Oxid. Med. Cell. Longev., 3173281 (2020).

9. A. M. Gbaguidi, F.J. Chadare, V. K. Salako, Y. O.V. Idohou and A. E. Assogbadjo, "Optimisation of oven-drying of baobab leaves using a central composite design", Afc. Crop. Sci. J., 28 (S1), 15-26 (2020).

10. A. R. Mohamed Hanaa, Y. I. Sallam, A. S. El-Leithy and S. E. Aly, "Lemongrass (Cymbopogon citratus) essential oil as affected by drying methods", Ann. Agric. Sci., 57 (2), 113-116 (2020).

11. G. Thamkaew, I. Sjöholm and F. G. Galindo, "A review of drying methods for improving the quality of dried herbs", Crit. Rev. Food Sci. Nutr. (2020).

12. Q. W. Zhang, L. G. Lin and W. C. Ye, "Techniques for extraction and isolation of natural products: A comprehensive review", Chin. Med., 13, 20 (2018).

13. S. A. F. Kusuma, S. R. Mita, I. Firdayani and R. Mustarichie, "Study on the antibacterial activity of fruit extracts of klutuk banana (Musa balbisiana Colla) against Shigella dysenteriae ATCC 13313", Asian. J. Pharm. Clin. Res., 10 (7), 220-223 (2017).

14. K. Vijayan, M. Gopinathan and V. Ambikapathy, "Phytochemical screening and antioxidant activity of Diospyros ebenum J. koening ex retz, leaves extract", Int. J. Pharm. Sci. Res., 11 (10), 51635169 (2020).

15. Z. Ahmed, S. Aziz, M. Hanif, S. G. Mohiuddin, S. H. A. Khan, R. Ahmed, S. M. S. Ghadzi and A. N. Bitar, "Phytochemical screening and enzymatic and antioxidant activities of Erythrina suberosa (Roxb) bark", J. Pharm. Bioallied. Sci., 12 (2), 192-200 (2020).

16. S. D. Ardhany, "Antibacterial activity of bawang dayak (Eleutherine sp.) and tawas ut (Ampelocissus sp.) from Central Kalimantan against Propionibacterium 
acnes", Int. J. App. Pharm., 11 (Special issue 3), 7-10 (2019).

17. R. Roghini and K. Vijayalakshmi, "Phytochemical screening, quantitative analysis of flavonoids and minerals in ethanolic extract of Citrus paradise", Int. J. Pharm. Sci. Res., 9 (11), 4859-4864 (2018).

18. T. Sathishkumar and R. Baskar, "Screening and quantification of phytochemicals in the leaves and flowers of Tabernaemontana heyneana Wall. A near threatened medicinal plant", Indian J. Nat. Prod. Resour., 5 (3), 237-243 (2014).

19. Sukmawati, S. Sudewi and J. Pontoh, "Optimasi dan validasi metode analisis dalam penentuan kandungan total flavonoid pada ekstrak daun gedi hijau (Abelmoscus manihot L.) yang diukur menggunakan spektrofotometri uv-vis", Pharmacon. Journal Ilmiah. Farmasi., 7 (3), 32-41 (2018).

20. A. E. Z. Hasan, H. Nashrianto, R. N. Juhaeni and I. M. Artika, "Optimization of conditions for flavonoids extraction from mangosteen (Garcinia mangostana L.)", Der. Pharmacia Lettre, 8 (18), 114-120 (2016).

21. B. B. Beyene, F. A. Alem and M. T. Ayana, "Determination of antioxidant and antibacterial activities of leaf extracts of Plumbago zeylanica (Amira)", Cogent. Chemistry, 6, 1831715, 1-16 (2020).

22. J. Hayat, M. Akodad, A. Moumen, M. Baghour, A. Skalli, S. Ezrari and S. Belmalha, "Phytochemical screening, polyphenols, flavonoids and tannin content, antioxidant activities and FTIR characterization of Marrubium vulgare L. from 2 different localities of Northeast of Morocco", Heliyon, 6 (11), e05609 (2020).

23. A. Rebaya, S. I. Belghith, B. Baghdikian, V. M. Leddet, F. Mabrouki, E. Olivier, J. K. Cherif and M. T. Ayadi, "Total phenolic, total flavonoid, tannin content, and antioxidant capacity of Halimium halimifolium (Cistaceae)", J. App. Pharm. Sci., 5 (01), 052-057 (2015).

24. F. Medini, H. Fellah, R. Ksouri and C. Abdelly, "Total phenolic, flavonoid and tannin contents and antioxidant and antimicrobial activities of organic extracts of shoots of the plant Limonium delicatulum", J. Taibah Univ. Sci., 8, 216-224 (2014).

25. A. S. N. Formagio, C. R. F. Volobuff, M. Santiago, C. A. L. Cardoso, M. D. C. Vieira and Z. V. Pereira, "Evaluation of antioxidant activity, total flavonoids, tanins and phenolic compounds in Psychotria leaf extracts". Antioxidants, 3, 745-757 (2014).

26. M. Manssouri, M. Znini and L. Majidi, "Studies on the antioxidant activity of essential oil and various extracts of Ammodaucus leucotrichus Coss. \& Dur. fruits from Morocco". J. Taibah Univ. Sci., 14 (1), 124-130 (2020).

27. S. D. Ardhany, D. S. Mulia and P. Rosawanti, "Antioxidant activity of ethyl acetate fraction of Macaranga triloba leaves from Central Kalimantan", Asian. J. Pharm. Clin. Res., 11 (3), 40-42 (2018).

28. J. Sukweenadhi, O. Yunita, F. Setiawan, Kartini, M. T. Siagian, A. P. Danduru and C. Avanti, "Antioxidant activity screening of seven Indonesian herbal extract", Biodiversitas, 21 (5), 2062-2067 (2020).

29. A. I. Andres, M. J. Petron, A. M. Lopez and M. L. Timon, "Optimization of extraction conditions to improve phenolic content and in-vitro antioxidant activity in craft brewers' spent grain using response surface methodology (RSM)", Foods, 9 (1398), 1-13 (2020).

30. K. Mitrevska, S. Grigorakis, S. Loupassaki and A. C. Calokerinos, "Antioxidant activity and polyphenolic content of North Macedonian wines", App. Sci., 10, 1-10 (2020).

31. S. Senhaji, F. Lamchouri and H. Toufik, "Phytochemical content, antibacterial and antioxidant potential of endemic plant Anabasis aretioides Coss. \& Moq. (Chenopodiaceae)", Bio. Res. Int., 1-16 (2020).

32. S. Mondal and S. T. Rahaman," Flavonoids: A vital resource in healthcare and medicine", Pharm. Pharmacol. Int. J., 8 (2), 91-104 (2020).

33. R. J. Nijveldt, E. van Nood, D. E. C. van Hoorn, P. G. Boelens, K. van Norren and P. A. M. van Leeuwen, "Flavonoids: A 
review of probable mechanisms of action and potential applications", Am. J. Clin. Nutr., 74, 418-25 (2001).

34. A. N. Panche, A. D. Diwan and S. R. Chandra, "Flavonoids: An overview", $\boldsymbol{J}$. Nutr. Sci., 5 (e47), 1-15 (2016).

35. J. Gan, Y. Feng, Z. He, X. Li and H. Zhang, "Correlations between antioxidant activity and alkaloids and phenols of Maca (Lepidium meyenii)", J. Food Quality, Article ID 3185945, 1-10 (2017).

36. G. Maisetta, G. Batoni, P. Caboni, S. Esin, A. C. Rinaldi and P. Zucca, "Tannin profile, antioxidant properties, and antimicrobial activity of extracts from two Mediterranean species of parasitic plant Cytinus", BMC Comp. \& Alt. Med., 19 (82), 1-11 (2019).

37. A. Thawabteh, S. Juma, M. Bader, D. Karaman, L. Scrano, A. S. Bufo and R. Karaman, "The biological activity of natural alkaloids against herbivores, cancerous cells and pathogens", Toxins, 11 (656), 1-28 (2019).

38. K. Macáková, V. Kolečkár̆, L. Cahlíková, J. Chlebek, A. Hošt’álková, K. Kuča, D. Jun and L. Opletal, "Tannins and their influence on health", Recent Adv. Medicinal Chemist., 1, 159-208 (2014).

39. K. Ambri, Y. Afifuddin and A. Hafni, "Exploration of medical plant in gunung leuser national park, sei betung resort, north sumatera", Peronema Forestry Science J., 4 (2), 19-32 (2015).

40. S. Kumar, R. Kumari and S. Mishra, "Pharmacological properties and their medicinal uses of Cinnamomum: A review", J. Pharm. and Pharm., 71, 1735-1761 (2019).

41. W. Yuan, H. W. Lee and H. G. Yuk, "Antimicrobial efficacy of Cinnamomum javanicum plant extract against Listeria monocytogenes and its application potential with smoked salmon", Int. J. Food Microbiology, 260, 42-50 (2017).

42. C. S. Vairappan, T. Nagappan and J. Kulip, "The essential oils profiles and antibacterial activity of six wild
Cinnamomum species", Nat. Prod. Commun., 9 (9), 1387-1389 (2014).

43. S. F. Najafabadi, L. Safaeian and B. Zolfaghari, "In-vitro antioxidant effects of different extracts obtained from the leaves and seeds of Allium ampeloprasum subsp. persicum", J. Herb. Pharm., 8 (3), 256260 (2019).

44. R. P. P. Fernandes, M. A. Trindade, F. G. Tonin, C. G. Lima, S. M. P. Pugine, P. E. S. Munekata, J. M. Lorenzo and M. P. de Melo, "Evaluation of antioxidant capacity of 13 plant extracts by three different methods: Cluster analyses applied for selection of the natural extracts with higher antioxidant capacity to replace synthetic antioxidant in lamb burgers", $\boldsymbol{J}$. Food Sci. Technol., 53 (1), 451-460 (2016).

45. W. M. N. Hakimi Wan Salleh, F. Ahmad and K. H. Yen, "Evaluation of antioxidant, anticholinesterase and antityrosinase activities of Malaysian Cinnamomum species", Dhaka Univ. J. Pharm. Sci., 14 (2), 125-132 (2015).

46. N. Liang and D. D. Kitts, "Antioxidant property of coffe components: Assessment of methods that define mechanisms of action", Molecules, 19, 19180-19208 (2014).

47. F. Shahidi and Y. Zhong, "Measurement of antioxidant activity", J. Functional Foods, 18 (Part B), 757-781 (2015).

48. A. Hassan, Z. Akmal and N. Khan, "The phytochemical screening and antioxidants potential of Schoenoplectus triqueter L. Palla", J. Chem., 2020, 1-8 (2020).

49. D. W. Wilson, P. Nash, H. S Buttar, K. Griffiths, R. Singh, F. D. Meester, R. Horiuchi and T. Takahashi, "The role of food antioxidants, benefits of functional foods, and influence of feeding habits on the health of the older person: An overview", Antioxidants, 6 (4), 81 (2017). 


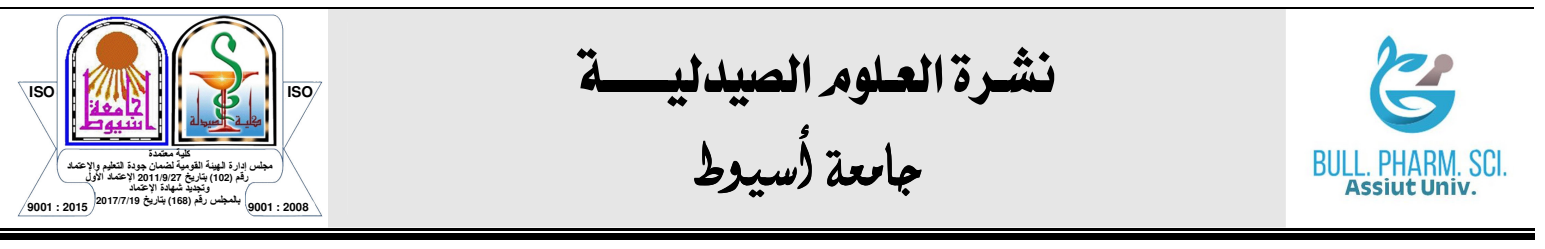

\section{المسح الكيميائي النباتي والفاعلية كمضادات الأكسدة لأوراق سينامومم جافانيكم

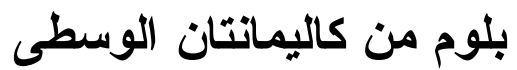

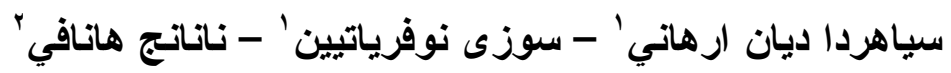

'قسم الصيدلة ، كليـة العلوم الصحية ، جامعـة المحمديـة في بالانغكارايـا ، بالانغكـا رايـا ، كاليمانتـان الوسطى ، إندونيسيا

'قسم الغابـات ، كلية الزراعة والغابات ، جامعة المحمدية في بالانكارايا ، بالانجكا رايا ، كاليمانتـان الوسطى ، إندونيسيا

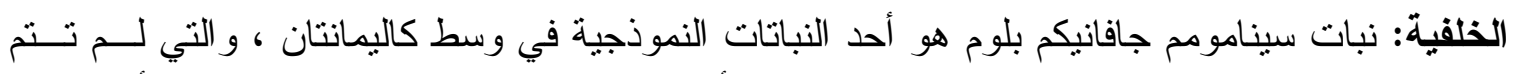

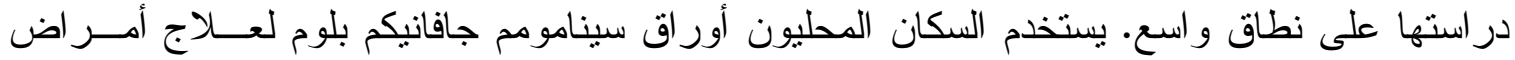

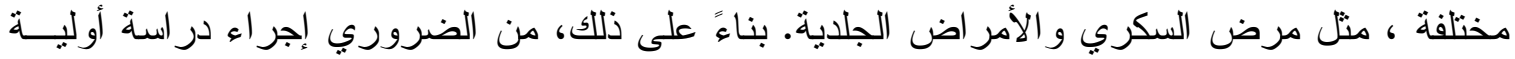
لمعرفة المحتوى الكيميائي النباتي و الفاعلية كمضادات الأكسدة لهذا النبات.

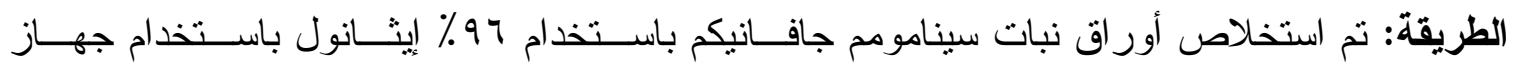

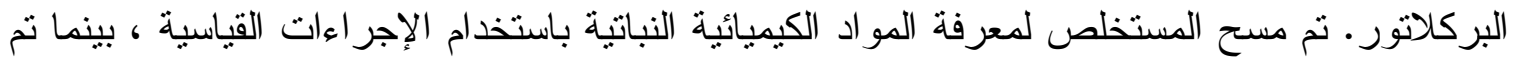

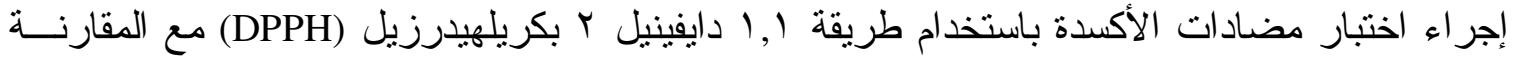
مع كورسيتين كمرجع وطريقة FRAP بالمقارنة مع ترولوكس كمعيار .

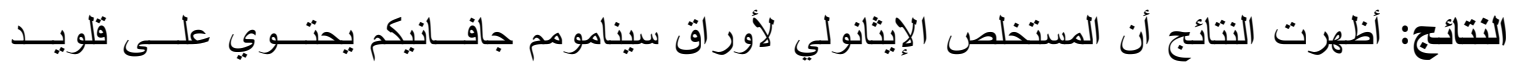

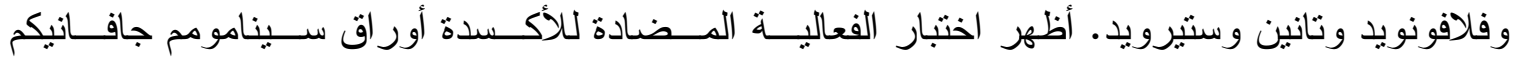

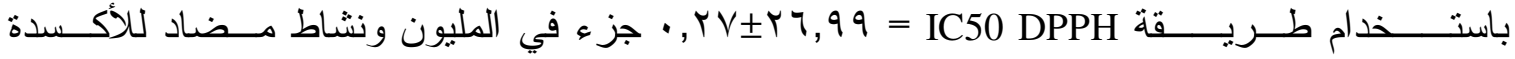

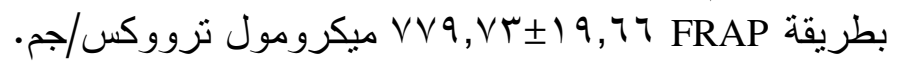

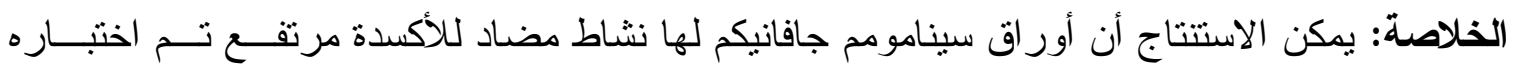

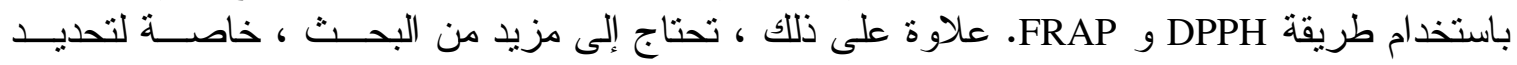
مركبات معينة من أور اق سينامومم جافانيكم. 